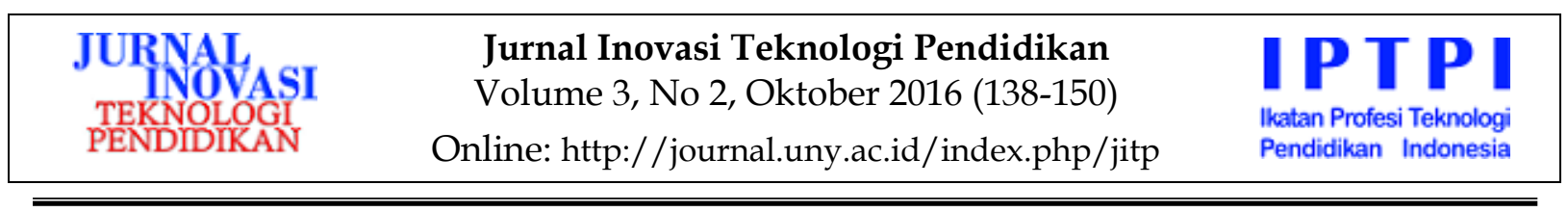

\title{
PENGEMBANGAN WEBSITE INTERAKTIF SEBAGAI COMPUTER-MEDIATED COMMUNICATION UNTUK PEMBELAJARAN JARINGAN KOMPUTER.
}

\author{
Ariyawan Agung Nugroho, Sunaryo Soenarto \\ Fakultas Ilmu Pendidikan UNY, Fakultas Teknik UNY \\ hoxs21@yahoo.com, sunaryos@uny.ac.id
}

\begin{abstract}
Abstrak
Penelitian ini bertujuan untuk mengembangkan sebuah website sebagai sarana computer-mediated communication (CMC) yang dapat membantu pembelajaran jaringan komputer yang layak, dinilai dari aspek pembelajaran, aspek isi/materi, aspek tampilan dan aspek pemrograman. Penelitian dan pengembangan (research and development) ini dilakukan melalui beberapa tahap, yaitu planning, design, development dan implementation. Penelitian dilakukan di Jurusan Teknologi Pendidikan, Fakultas Ilmu Pendidikan, UNY. Hasil penelitian ini adalah website interaktif sebagai computer-mediated communication yang kelayakan pada aspek pembelajaran produk ini termasuk dalam kategori baik berdasarkan skor dari ahli materi satu yaitu 4,16 dan termasuk dalam kategori sangat baik berdasarkan skor dari ahli materi dua sejumlah 4,33, kelayakan aspek isi/materi termasuk dalam kategori sangat baik berdasarkan kedua skor ahli materi, dengan masing-masing ahli memberikan skor nilai 4,72 dan 4,45 kelayakan aspek media termasuk dalam kategori sangat baik berdasarkan nilai skor yang diberikan masing-masing ahli, yaitu 4,55 dari ahli media satu, dan 4,6 dari ahli media dua.
\end{abstract}

Kata kunci: website, interaktif, computer-mediated communication, CMC

\section{DEVELOPMENT OF INTERACTIVE WEBSITE AS COMPUTER-MEDIATED COMMUNICATION MEDIA FOR COMPUTER NETWORKS INSTRUCTION}

\author{
Ariyawan Agung Nugroho, Sunaryo Soenarto \\ Fakultas Ilmu Pendidikan UNY, Fakultas Teknik UNY \\ hoxs21@yahoo.com, sunaryos@uny.ac.id
}

\begin{abstract}
The research aimed at developing an appropriate interactive website which serves as computermediated communication (CMC), that supports the learning process of Computer Network, evaluated on the bases of learning, content, layout and programming. This research and development was carried out through a set of procedures involving planning, design, development and implementation. This research was conducted in Educational Technology Department, Faculty of Educational Science, YSU. The research findings showed that the interactive website providing computer-mediated communication has been considered appropriate for use. In term of learning aspect, this website was scored 4.16 or 'good' by the first content expert and 4.33 or very good by the second content expert. Meanwhile, its material aspect was scored 4.72 by the first content expert and 4.45 by the second. Both mean scores are categorized as very good. Its media appropriateness was considered very good by both media experts, each of whom scored 4.55 and 4.6 respectively.
\end{abstract}

Keywords: website, interactive, computer-mediated communication, CMC 



\section{Pendahuluan}

Perkembangan teknologi informasi sangat cepat dan menawarkan banyak kemudahan bagi manusia dalam memperoleh informasi dalam hitungan detik. Pemenuhan kebutuhan manusia akan informasi pada saat ini menjadi begitu mudah dengan hadirnya internet, yang memberikan layanan transfer informasi dalam waktu yang cepat. Perbedaan jarak, waktu dan ruang tidak lagi menjadi persoalan. Riza (2012) memaparkan bahwa Indonesia saat ini menempati posisi tiga besar untuk pengguna internet di dunia, meningkat sebanyak 58 persen dari jumlah tahun 2011. Lepas dari tujuan penggunaannya, publikasi ini menunjukkan bahwa pemanfaatan teknologi internet seperti e-mail, chat, website, dan sebagainya di Indonesia tergolong besar dan terus meningkat. Masyarakat Indonesia sendiri sudah banyak mengenal teknologi ini. Kemudahan ini memberikan keuntungan tersendiri bagi mereka yang jauh dari sumber informasi dan sebagai alat berkomunikasi. Perkembangan teknologi internet memunculkan berbagai aplikasi baru termasuk di bidang pendidikan.

Komputer menjadi primadona karena penggunaannya yang sangat beragam dalam penerapannya. Hal ini sejalan dengan pendapat Putra \& Ishartiwi (2015), bahwa salah satu produk teknologi yang dapat digunakan sebagai inovasi dalam pembelajaran adalah komputer. Internet adalah salah satu bagian dalam teknologi komputer yang dapat dimanfaatkan dalam pembelajaran. Salah satu manfaat teknologi internet dalam bidang pendidikan adalah sebagai sarana pembelajaran. Beberapa fasilitas di internet, seperti website, chat, email kemudian dimanfaatkan untuk mendukung proses pembelajaran, yang kemudian dikenal dengan sebutan e-learning. Sistem e-learning yang menggunakan internet saat ini juga telah berkembang dengan pesat, seiring dengan teknologi yang berkembang dan pengguna internet yang terus meningkat. Proses belajar mengajar yang biasanya dilakukan di kelas, dapat dilakukan melalui internet secara jarak jauh tanpa harus tatap muka. Melalui teknologi ini seorang dosen mengajar di depan sebuah komputer yang ada di suatu tempat, sedangkan para mahasiswa mengikuti pelajaran tersebut dari komputer lain di tempat yang berbeda dan pada saat yang bersamaan (synchronous), atau bisa juga dosen memberikan materi dan soal evaluasi, kemudian mahasiswa dapat mengaksesnya kapan saja, tidak perlu dalam waktu yang bersamaan dengan dosennya (asynchronous). Teknologi ini memiliki efisiensi dan efektifitas dalam membantu proses belajar mengajar, dan kemudian teknologi e-learning ini dapat menjadi sebuah solusi dan teknologi alternatif untuk digunakan dalam model pembelajaran. Teknologi internet berbasis teks yang membantu dalam melakukan komunikasi ini yang kemudian disebut dengan komunikasi yang dimediasi komputer (computer-mediated communication-CMC).

CMC akhir-akhir ini banyak di gunakan untuk komunikasi interpersonal antara keluarga, teman dan bahkan orang lain. Di perguruan tinggi, telah banyak penelitian yang mengemukakan efektivitas dan efisiensi CMC dalam proses pembelajaran dimana CMC mempersempit perbedaaan jarak dan waktu, sehingga mengoptimalkan interaksi dosen dan mahasiswa. Mengingat interaksi dosen dan mahasiswa menentukan kualitas proses pembelajaran di kelas, keberadaan CMC sangat membantu tercapainya tujuan pembelajaran dan terciptanya komunitas belajar (learning community) yang optimal.

Komunitas belajar akan tercipta bila terselenggara interaksi antara dosen dan mahasiswa yang baik selama proses pembelajaran di perguruan tinggi. Interaksi yang positif di kelas dipengaruhi oleh beberapa faktor, baik dari dosen, mahasiswa, materi maupun media yang digunakan dalam proses pembelajaran. Mahasiswa memiliki peran signifikan dalam menentukan apakah sebuah kelas memiliki komunitas belajar yang established atau tidak 
yang diindikasikan dengan tingkat partisipasi dan interaksi di kelas. Partisipasi di kelas yang tinggi menunjukkan bahwa mahasiswa telah memiliki rasa nyaman berinteraksi dengan warga kelas yang merefleksikan rendahnya rasa cemas dan tingginya kepercayaan antara sesama mahasiswa di kelas sebagai sebuah komunitas belajar. Partisipasi aktif mahasiswa juga mendorong pemahaman yang konstrukif, karena apa yang disampaikan salah seorang mahasiswa sangat berpotensi mendorong terbentuknya pemahaman bagi siswa lain. Disamping itu, partisipasi aktif mahasiswa sering menjadi tolak ukur pencapaian belajar mahasiswa. Karenanya, tingkat partisipasi dalam proses pembelajaran perlu ditingkatkan dengan menciptakan media komunikasi yang meminimalisir kecemasan mahasiswa akan kehausan berbicara di ruang publik. Teknologi melalui metode CMC sering kali dimanfaatkan untuk meningkatkan partisipasi mahasiswa di kelas.

Dalam observasi yang dilakukan ditemukan bahwa, pada kelas Jaringan Komputer di jurusan Kurikulum dan Teknologi Pendidikan, sebagian besar mahasiswa tidak merespon pertanyaan maupun komentar dari dosen. Ketika diberikan pertanyaan dengan tingkat kesulitan yang bervariasi, hanya sebagian kecil yang merespon. Dengan kata lain, partisipasi mahasiswa di kelas tersebut rendah dan karenanya menyebabkan interaksi kelas yang kurang optimal. Dari kasus tersebut, ditemukan bahwa rendahnya partisipasi mahasiswa di kelas tersebut diantaranya disebabkan oleh faktor-faktor berikut: 1) kurangnya kemampuan awal (entry behaviour) dan ketrampilan mahasiswa dalam bidang Jaringan Komputer membuat mahasiswa urung dan cenderung enggan dalam berinteraksi dengan dosen, 2) kurangnya pengetahuan/ketrampilan yang dimiliki mahasiswa menyebabkan mereka kurang memiliki rasa percaya diri dan cemas (anxious) dalam mengungkapkan gagasannya, dan 3) terbatasnya durasi pertemuan selama perkuliahan berpengaruh terhadap kesempatan dosen untuk memberikan input serta waktu untuk berinteraksi di kelas. Hal tersebut mendorong dosen yang juga penulis untuk mencari solusi yang dapat menjembatani interaksi dosen dan mahasiswa, sehingga partisipasi mahasiswa di kelas akan lebih optimal dengan mempertimbangkan karakteristik atau kondisi mahasiswa tersebut. Solusi yang dapat diterapkan adalah penggunaan computer mediated communicationatau CMC yang dapat bersifat synchronous maupun asynchronous.

\section{Metode Penelitian}

Penelitian ini bertujuan untuk mengembangkan website interaktif sebagai wahana computer-mediated communication di kelas Jaringan Komputer. Untuk mencapai tujuan tersebut, penelitian ini menggunakan metode Research and Development (R\&D). Penelitian dilakukan di Jurusan Kurikulum dan Teknologi Pendidikan, Fakultas Ilmu Pendidikan, Universitas Negeri Yogyakarta dalam kurun waktu Juli - Desember 2014 dengan mengambil mahasiswa kelas Jaringan Komputer, sebagai subjek penelitian. Subjek penelitian dipilih secara purposive yaitu mahasiswa jurusan Kurikulum dan Teknologi Pendidikan yang mengikuti kelas Jaringan Komputer yang diampu penulis.

Prosedur dalam penelitian ini diadopsi dari berbagai model pengembangan, yakni model pengembangan ADDIE, model pengembangan Alessi Trolip serta model pengembangan waterfal. Prosedur pengembangan yang digunakan dalam penelitian ini meliputi planning, design, development dan implementation (uji coba). Data yang diperoleh dalam penelitian ini meliputi data kualitatif yang berupa tanggapan mahasiswa sebagai responden dalam survei kebutuhan, dan data kuantitatif yang berasal dari tanggapan ahli materi dan ahli media terhadap kelayakan website interaktif yang dikembangkan, serta dari tanggapan mahasiswa sebagai subjek uji coba, yang hasil tanggapannya kemudian diangkakan sehingga menjadi data kuantitatif. 
Instrumen yang digunakan mencakup angket evaluasi materi dan media, serta angket evaluasi hasil uji coba. Masing-masing angket tersebut berisi poin yang berbeda, sesuai dengan peruntukannya. Kisi-kisi angket validasi untuk ahli materi dimodifikasi dari Dick \& Carrey (2009, pp. 218-219), yang kemudian dikelompokkan menjadi aspek pembelajaran dan aspek materi. Pada setiap aspek kemudian dikembangkan komponen dan indikatornya. Sedangkan kisi-kisi angket validasi untuk ahli media dimodifikasi dari pendapat Suyanto (2007, pp.61-69) tentang penilaian website yang baik. Dalam penilaian tersebut komponen penilaian terdiri dari beberapa komponen, seperti penggunaan, navigasi, desain visual, konten, kompatibilitas, waktu proses dan interaktifitas.

Data yang diperoleh melalui kegiatan uji coba diklasifikasikan menjadi 2, yaitu data kualitatif dan data kuantitatif. Data kualitatif dalam penelitian ini berupa kritik dan saran yang dikemukakan ahli materi, ahli media, dan mahasiwa. Datadata ini dihimpun kemudian diambil maksudnya, yang kemudian digunakan untuk memperbaiki produk website interaktif. Sedangkan data kuantitatif berupa skor angket dari ahli materi dan ahli media dan skor tes mahasiswa pada saat uji coba produk yang dikembangkan. Teknik yang digunakan untuk memberikan kriteria nilai kualitas produk yang dibuat yaitu: (1) data yang diperoleh dari angket diubah dahulu menjadi data interval yang meliputi: sangat baik (5), baik (4), cukup (3), kurang baik (2), dan sangat kurang baik (1). Seandainya responden memberikan tanggapan "sangat baik" pada butir pertanyaan, maka skor butir pertanyaan tersebut sebesar " 5 " dan seterusnya; (2) skor yang diperoleh dari validasi produk dengan angket tersebut kemudian dijumlahkan dan dibuat ratarata, selanjutnya dikonversi menjadi nilai pada skala lima dengan acuan tabel yang diadaptasi dari Sukarjdo (2010, pp. 100101) sebagaimana disajikan pada Tabel 1.
Tabel 1. Konversi Skor menjadi Nilai Pada Skala Lima

\begin{tabular}{ll}
\hline $\begin{array}{l}\text { Nilai/ } \\
\text { Kategori }\end{array}$ & Interval \\
\hline Sangat Baik & $X>\bar{X}_{l}+1,80 \mathrm{Sbi}$ \\
Baik & $\bar{X}_{l}+0,60 \mathrm{Sbi}<\mathrm{X} \leq \bar{X}_{l}+1,80 \mathrm{Sbi}$ \\
Cukup Baik & $\bar{X}_{l}-0,60 \mathrm{Sbi}<\mathrm{X} \leq \bar{X}_{l}+0,60 \mathrm{Sbi}$ \\
Kurang Baik & $\bar{X}_{l}-1,80 \mathrm{Sbi}<\mathrm{X} \leq \bar{X}_{l}-0,60 \mathrm{Sbi}$ \\
Sangat & $X \leq \bar{X}_{l}-1,80 \mathrm{Sbi}$ \\
Kurang Baik & \\
\hline
\end{tabular}

\section{Hasil Penelitian dan Pembahasan}

Pengembangan website interaktif sebagai wahana computer-mediated communication untuk pembelajaran Jaringan Komputer dikembangkan melalui tahap planning, design, development dan implementation. Pada tahap planning dilakukan identifikasi kebutuhan belajar peserta didik, dan studi pustaka untuk mengetahui ruang lingkup, karakterstik peserta didik, sistem yang potensial serta penentuan waktu penelitian. Data yang diperoleh dari tahap planning sebagai berikut: (1) mahasiswa secara umum cenderung memilih sumber belajar dari internet dibandingkan buku teks atau sumber belajar lainnya yang mungkin dikarenakan pengetahuan yang tersedia di internet sangat luas, serta bisa menunjukkan cara kerja, gambar-gambar, atau materi secara lebih mendetail, dan tersedia baik secara audio/visual dan menjadikan proses pencarian pengetahuan menjadi lebih menarik; (2) karakteristik mahasiswa secara umum terbagi menjadi dua kelompok, yaitu mahasiswa yang berpartisipasi aktif dan yang kurang aktif di dalam kelas yang disebabkan oleh rasa enggan/sungkan untuk berinteraksi secara langsung dengan pengajarnya dikarenakan oleh berbagai faktor misalnya kurangnya rasa percaya diri mahasiswa dalam bertanya atau berpartisipasi di kelas, terbatasnya latar belakang pengetahuan mahasiswa tentang materi yang diajarkan, jam perkuliahan yang terbatas, dan sebagainya.

Sementara itu, kegiatan studi pustka tentang kurikulum, silabus mata kuliah 
Jaringan Komputer, buku-buku tentang website interaktif dan penggunaan komputer dalam pembelajaran diperoleh data: (1) mata kuliah Jaringan Komputer dapat memanfaatkan komputer sebagai media tambahan untuk membantu mahasiswa memahami lebih baik materi yang diberikan, (2) mahasiswa sangat membutuhkan variasi kegiatan pembelajaran yang memfasilitasi komunikasi dua arah antara dosen dan mahasiswa, serta antara mahasiswa dan mahasiswa secara efektif dan komunikatif melalui website interaktif, (3) penggunaan website interaktif mempunyai dampak yang sangat baik terhadap proses dan hasil belajar, tidak hanya sebagai sarana berkomunikasi dosen dan mahasiswa yang dimediasi komputer atau computer-mediated communication yang memfasilitasi proses pembelajaran di kelas, penggunaan website interaktif juga memberikan kesempatan pengalaman kepada mahasiswa untuk mempraktikkan pemanfaatan jaringan komputer dalam proses pembelajaran.

Hasil data yang diperoleh dari studi pustaka dan studi lapangan selanjutnya dijadikan sebagai bahan pertimbangan dan masukan untuk mendesain serta mengembangkan produk wahana computermediated communication untuk pembelajaran Jaringan Komputer. Pengembangan wahana computer-mediated communication ini dilakukan dengan menggunakan bahasa pemrograman PHP, basis data mySQL, dan CodeIgniter framework, serta menggunakan hosting berkas di idwebhost.com, sedangkan alamat domain website interaktif menginduk pada domain ariyawan.com, dan diberi nama sub-domain jarkomtp, sehingga website dapat di akses dengan alamat domain ariyawan.net/jarkom.

Bahasa pemrograman yang digunakan adalah bahasa pemograman untuk web, yaitu PHP (PHP Hypertext Preprocessor) yang dikombinasikan dengan penggunaan AJAX (Asynchronous Java-Script and $X M L)$, yang memungkinkan website ini tetap berjalan, seperti mengambil data atau mengirim data ke server, tanpa mempeng- aruhi tampilan muka pada pengguna. Dan sebagai framework, digunakan codeigniter framework untuk memudahkan dalam pengembangan website. Pengembangan yang dilakukan berjalan dengan lancar dan terencana karena didasarkan pada sitemap, desain, baik interface maupun basisdata dan DFD yang telah dibuat sebelumnya, juga didukung dengan kesiapan peralatan yang diperlukan.

Proses pengembangan produk dilakukan dengan merencanakan database yang digunakan, disesuaikan dengan entitas yang terlibat. Proses pengembangan kemudian dilanjutkan dengan pembuatan sitemap website, yaitu suatu diagram alur yang menjelaskan mengenai peta dalam website, supaya dalam pengembangannya lebih terarah. Pengembangan sitemap kemudian dilanjutkan dengan membuat sketsa interface/storyboard yang dikembangan. Berdasarkan beberapa hal yang telah dibuat tersebut, kemudian dilakukan proses coding, dengan terlebih dahulu membuat server lokal dengan menggunakan xampp dan menyesuaikan pengaturan pada framework codeigniter yang kita pakai. Setelah itu dilanjutkan dengan proses pembuatan basisdata dan tabel dengan menggunakan MySQL, dan diteruskan dengan proses coding dengan memanfaatkan bahasa pemrograman PHP dan AJAX. Produk kemudian di unggah pada server host berbayar, untuk mengetahui tingkat kompatibilitasnya terhadap server tersebut.

Wahana computer-mediated communication untuk pembelajaran Jaringan Komputer secara garis besar memiliki komponen sebagai berikut: (a) otentifikasi pengguna, yang diberikan melalui nama pengguna dan kata sandi; (b) dua tingkat akses, yaitu administrator dan pengguna biasa, dimana administrator memiliki seluruh akses yang ada pada website, termasuk dalam membuat kategori, melakukan kustomisasi isi, dan beberapa fitur lainnya, sedangkan pengguna biasa hanya memiliki akses dalam memanfaatkan dan berinteraksi saja; (c) pada halaman utama terdapat materi yang bisa diakses dan halaman 
interaksi yang dapat dimanfaatkan oleh para pengguna; (d) materi yang dimasukkan terdiri dari beberapa materi yang dikembangkan dari beberapa bagian silabus; (d) wahana untuk berkomunikasi difasilitasi dengan bentuk komentar pada setiap materi, dan rating baik pada materi ataupun pada setiap komentar yang diberikan; serta (e) akses bagi pengguna untuk mengatur preferensi profil mereka, untuk menampakkan siapa pengguna tersebut, mulai dari nama asli, foto, e-mail, sampai pada menu penggantian password.

\section{Hasil Validasi Materi}

Data validasi ahli materi diperoleh dengan cara menunjukkan produk dalam bentuk website interaktif yang dapat diakses atau dicoba secara langsung, dilengkapi dengan printed out materi, dan menggunakan angket skala likert yang mencakup aspek pembelajaran dan isi/materi. Deskripsi validasi ahli materi terhadap website hasil pengembangan sebagai berikut. Terdapat dua aspek yang dinilai yaitu aspek pembelajaran dan aspek materi.

Tabel 2. Hasil validasi dari Ahli Materi 1 pada Aspek Pembelajaran

\begin{tabular}{|c|c|c|}
\hline No Indikator & $\begin{array}{l}\text { Vali- } \\
\text { dasi } 1 \\
\end{array}$ & $\begin{array}{l}\text { Vali- } \\
\text { dasi } 2\end{array}$ \\
\hline $\begin{array}{l}\text { 1. Sistematika dalam } \\
\text { menyajikan materi Jaringan } \\
\text { Komputer }\end{array}$ & 5 & 5 \\
\hline $\begin{array}{l}\text { 2. Kejelasan materi Jaringan } \\
\text { Komputer }\end{array}$ & 4 & 4 \\
\hline $\begin{array}{l}\text { 3. Kejelasan pemberian petunjuk } \\
\text { belajar }\end{array}$ & 2 & 4 \\
\hline $\begin{array}{l}\text { 4. Variasi cara menyajikan } \\
\text { materi }\end{array}$ & 3 & 3 \\
\hline $\begin{array}{l}\text { 5. Kejelasan pemberian } \\
\text { contoh/ilustrasi dalam materi }\end{array}$ & 5 & 5 \\
\hline $\begin{array}{l}\text { 6. Kejelasan petunjuk / instruksi } \\
\text { belajar }\end{array}$ & 4 & 4 \\
\hline Rerata Skor & 3,83 & 4,16 \\
\hline
\end{tabular}

Dari keenam indikator aspek pembelajaran dalam produk penelitian ini, terdapat satu indikator yaitu kejelasan pemberian petunjuk belajar yang dipandang ahli materi 1 'kurang baik' dan karenanya perlu direvisi. Setelah direvisi, indikator tersebut dianggap 'baik'. Secara keseluruhan, keenam indikator aspek pembelajaran dari segi materi mendapat rerata 3,83 atau baik sebelum direvisi, dan setelah direvisi memperoleh rerata 4,16 atau baik. Sejalan dengan hal ini, ahli materi 1 memberikan masukan agar pemberian petunjuk belajar diperjelas melalui penjabaran langkahlangkah kegiatan pembelajaran yang perlu dilakukan mahasiswa atau pemberian contoh mengerjakan atau menyelesaikan suatu tugas atau latihan.

Aspek berikutnya yang dinilai adalah aspek isi atau materi yang hasil validasinya dapat dilihat pada Tabel 3.

Tabel 3. Hasil validasi dari Ahli Materi 1 pada Aspek Isi/Materi

\begin{tabular}{|c|c|c|c|}
\hline$\overline{\text { No }}$ & Indikator & $\begin{array}{l}\text { Vali- } \\
\text { dasi } 1\end{array}$ & $\begin{array}{l}\text { Vali- } \\
\text { dasi } 2\end{array}$ \\
\hline 1. & $\begin{array}{l}\text { Keseimbangan materi dengan } \\
\text { latihan }\end{array}$ & 5 & 5 \\
\hline 2. & $\begin{array}{l}\text { Kemudahan dalam } \\
\text { memahami materi }\end{array}$ & 5 & 5 \\
\hline 3. & $\begin{array}{l}\text { Aktualitas materi yang } \\
\text { disampaikan }\end{array}$ & 5 & 5 \\
\hline 4. & Urgensi setiap materi & 4 & 4 \\
\hline 5. & $\begin{array}{l}\text { Kesesuaian materi dengan } \\
\text { karakteristik mahasiswa }\end{array}$ & 4 & 4 \\
\hline 6. & $\begin{array}{l}\text { Tingkat faktualitas materi } \\
\text { untuk mencapai tujuan }\end{array}$ & 5 & 5 \\
\hline 7. & $\begin{array}{l}\text { Keluasan dan kedalam-an } \\
\text { materi }\end{array}$ & 5 & 5 \\
\hline 8. & $\begin{array}{l}\text { Ketepatan contoh / ilustrasi } \\
\text { yang diberikan }\end{array}$ & 4 & 5 \\
\hline 9. & $\begin{array}{l}\text { Kesesuaian gambar yang } \\
\text { digunakan }\end{array}$ & 4 & 4 \\
\hline & $\begin{array}{l}\text { Kesesuaian video yang } \\
\text { digunakan }\end{array}$ & 5 & 5 \\
\hline & Kejelasan penggunaan bahasa & 5 & 5 \\
\hline Jum & lah Skor & 51 & 52 \\
\hline Rer & ata Skor & 4,63 & 4,72 \\
\hline
\end{tabular}

Dari kesebelas indikator aspek materi yang digunakan dalam validasi produk penelitian ini, terdapat satu indikator yang meningkat dari proses validasi pertama dan kedua, yaitu ketepatan contoh/ilustrasi yang diberikan. Pada validasi per- 
tama, ahli materi 1 memberikan nilai 'baik' bagi pemberian contoh/ilustrasi dalam website interaktif yang dikembangkan. Pada validasi kedua, ahli materi 1 memberikan nilai 'sangat baik'. Secara keseluruhan, dari aspek materi, website interaktif yang dikembangkan dianggap sangat baik dalam validasi pertama dan kedua, dengan rerata skor 4,63 untuk validasi pertama, dan 4,72 untuk validasi kedua. Terkait hal ini, ahli materi 1 memberikan saran agar pemberian contoh/ilustrasi tidak hanya berupa audio maupun visual saja, tetapi juga disertai dengan keterangan atau penjelasan tentang informasi atau pengetahuan yang diberikan melalui contoh/ilustrasi berupa audio atau visual tersebut.

Pada validasi yang ke dua ahli materi memberikan komentar umum terhadap produk ini, yakni secara keseluruhan website interaktif yang dikembangkan sudah baik. Setelah memberikan komentar, ahli materi memberikan kesimpulan mengenai kelayakan produk yang dikembangkan dari aspek pembelajaran dan isi/materi. Adapun kesimpulannya adalah bahwa produk/program ini layak untuk uji coba lapangan.

Sementara itu, ahli materi 2 menilai aspek pembelajaran produk penelitian ini dengan rerata 4 untuk validasi pertama atau dalam kategori 'baik', dan 4,33 untuk validasi kedua, atau dengan kategori 'sangat baik'. Diantara keenam indikator di atas, indikator 'kejelasan pemberian petunjuk belajar' mengalami peningkatan dengan skor sebelum revisi 3 atau 'cukup' dan sesudah revisi mendapat skor 4 atau 'baik'. Indikator berikutnya yang mengalami peningkatan adalah kejelasan petunjuk/instruksi belajar yang sebelum revisi juga mendapat skor 3 atau 'cukup' dan 4 atau 'baik' setelah direvisi dan divalidasi kedua.

Disamping memberi rerata skor, ahli materi 2 juga memberikan masukan terkait dengan pemenuhan indikator yang dirasa perlu ditingkatkan. Dalam hal ini, ahli materi 2 menyarankan agar peneliti menyusun user manual yang akan memper- jelas pemberian petunjuk belajar dan instruksi dalam melakukan kegiatan pembelajaran menggunakan website interaktif yang dikembangkan. Selain itu, ahli materi 2 juga memberi masukan akan perlunya menambahkan introduction di bagian awal website sebagai petunjuk yang menjelaskan apa yang ditawarkan oleh website interaktif yang dikembangkan.

Tabel 4. Hasil Validasi Ahli Materi 2

\begin{tabular}{|c|c|c|c|}
\hline No & Indikator & $\begin{array}{l}\text { Vali- } \\
\text { dasi } 1\end{array}$ & $\begin{array}{l}\text { Vali- } \\
\text { dasi } 2\end{array}$ \\
\hline & $\begin{array}{l}\text { Keseimbangan materi } \\
\text { dengan latihan }\end{array}$ & 5 & 5 \\
\hline 2. & $\begin{array}{l}\text { Kemudahan dalam } \\
\text { memahami materi }\end{array}$ & 4 & 4 \\
\hline 3. & $\begin{array}{l}\text { Aktualitas materi yang } \\
\text { disampaikan }\end{array}$ & 5 & 5 \\
\hline 4. & Urgensi setiap materi & 4 & 4 \\
\hline 5. & $\begin{array}{l}\text { Kesesuaian materi dengan } \\
\text { karakteristik mahasiswa }\end{array}$ & 5 & 5 \\
\hline & $\begin{array}{l}\text { Tingkat faktualitas materi } \\
\text { untuk mencapai tujuan }\end{array}$ & 4 & 4 \\
\hline 7. & $\begin{array}{l}\text { Keluasan dan kedalaman } \\
\text { materi }\end{array}$ & 3 & 4 \\
\hline & $\begin{array}{l}\text { Ketepatan contoh / ilustrasi } \\
\text { yang diberikan }\end{array}$ & 5 & 5 \\
\hline & $\begin{array}{l}\text { Kesesuaian gambar yang } \\
\text { digunakan }\end{array}$ & 5 & 5 \\
\hline & $\begin{array}{l}\text { Kesesuaian video yang } \\
\text { digunakan }\end{array}$ & 4 & 4 \\
\hline & $\begin{array}{l}\text { Kejelasan penggunaan } \\
\text { bahasa }\end{array}$ & 4 & 4 \\
\hline \multicolumn{2}{|c|}{ Jumlah Skor } & 48 & 49 \\
\hline \multicolumn{2}{|c|}{ Rerata Skor } & 4,36 & 4,45 \\
\hline
\end{tabular}

Dari kesebelas indikator aspek materi yang digunakan untuk menilai website interaktif yang dikembangkan, ahli materi 2 memberi rerata skor 48 atau 'sangat baik' untuk validasi pertama, dan 49 atau 'sangat baik' untuk validasi kedua. Adapun peningkatan skor terletak pada indikator ketujuh yakni kedalaman atau keluasan materi, dimana sebelumnya ahli materi 2 memberi skor 3 atau 'cukup' dan setelah direvisi, pada validasi kedua memberi skor 4 atau 'baik'. Hal ini sejalan dengan saran yang diberikan ahli materi 2, bahwa materi perlu diperkaya dengan mencantumkan 
lebih banyak referensi terkini baik cetak maupun non-cetak dan disertai dengan contoh-contoh penerapannya.

\section{Revisi Produk Berdasarkan Validasi Materi}

Revisi yang dilakukan berdasarkan masukan dari ahli materi adalah sebagai berikut. Yang pertama adalah menambahkan perkenalan/intro pada awal bagian website. Perkenalan pada awal bagian website bertujuan untuk memberikan pemahaman tentang isi dan tujuan dari website. Ditambahkannya perkenalan/intro pada awal halaman website memunculkan ide baru untuk sekaligus menambahkan gambar banner pada awal halaman website, supaya website tidak terkesan sepi. Revisi yang kedua yaitu membuatkan buku manual pengguna untuk penggunaan website. Buku manual pengguna yang dibuat dibatasi hanya penggunaan pada saat website tersebut sudah terpasang pada server. Penggunaan yang dimaksud adalah manual penggunaan untuk pengguna admin, dan manual penggunaan untuk pengguna biasa. Manual penggunaan kemudian diunggah pada bagian awal website, supaya dapat dengan mudah diunduh. Revisi berikutnya meliputi menambah materi praktik berupa video tutorial yang dapat diunduh, serta menambahkan instruksi pada setiap materi yang ada.

\section{Validasi Ahli Media}

Hasil validasi oleh dua ahli media yang disajikan pada Tabel 5. Dari keduapuluh indikator untuk validasi media, ahli media 1 memberikan rerata skor 4,5 atau 'sangat baik' untuk validasi pertama, dan 4,55 atau 'sangat baik' untuk validasi kedua. Terdapat satu indikator yakni tingkat kesalahan penggunaan hyperlink yang sebelum direvisi mendapat skor 3 atau 'cukup' dan selanjutnya meningkat menjadi 4 atau 'baik' setelah direvisi. Hal ini sejalan dengan masukan yang diberikan ahli media 1 agar penggunaan hyperlink perlu dicek ulang karena saat dicoba ditemukan beberapa hyperlink yang tidak dapat diakses. Mengikuti saran ahli media 1, peneliti kemudian membuat ulang hyperlink untuk beberapa tautan yang disediakan di dalam website interaktif yang dikembangkan dalam penelitian ini.

Tabel 5. Hasil Validasi oleh Ahli Media Satu

\begin{tabular}{|c|c|c|c|}
\hline$\overline{\mathrm{No}}$ & Indikator & $\begin{array}{l}\text { Vali- } \\
\text { dasi } 1\end{array}$ & $\begin{array}{l}\text { Vali- } \\
\text { dasi } 2 \\
\end{array}$ \\
\hline & $\begin{array}{l}\text { Kemudahan website untuk } \\
\text { dipelajari }\end{array}$ & 5 & 5 \\
\hline 2. & Penggunaan website mudah & 5 & 5 \\
\hline & $\begin{array}{l}\text { Tingkat kesalahan } \\
\text { penggunaan hyperlink }\end{array}$ & 3 & 4 \\
\hline 4. & $\begin{array}{l}\text { Kejelasan navigasi yang } \\
\text { digunakan dalam website }\end{array}$ & 4 & 4 \\
\hline 5. & Konsistensi navigasi & 5 & 5 \\
\hline 6. & $\begin{array}{l}\text { Visualisasi tombol yang } \\
\text { digunakan mudah di pahami }\end{array}$ & 4 & 4 \\
\hline 7. & $\begin{array}{l}\text { Label navigasi mudah } \\
\text { dimengerti }\end{array}$ & 4 & 4 \\
\hline 8. & $\begin{array}{l}\text { Kesesuaian komposisi warna } \\
\text { yang digunakan dengan target } \\
\text { pengguna }\end{array}$ & 4 & 4 \\
\hline 9. & $\begin{array}{l}\text { Konsistensi layout dalam } \\
\text { website }\end{array}$ & 5 & 5 \\
\hline 10. & $\begin{array}{l}\text { Tata-letak (layout) bagian } \\
\text { website mudah dipetakan } \\
\text { dengan jelas }\end{array}$ & 5 & 5 \\
\hline 11. & $\begin{array}{l}\text { Tingkat keterbacaan teks } \\
\text { dalam website }\end{array}$ & 5 & 5 \\
\hline 12. & $\begin{array}{l}\text { Kualitas video yang } \\
\text { ditampilkan di dalam website }\end{array}$ & 4 & 4 \\
\hline 13. & $\begin{array}{l}\text { Kualitas gambar yang } \\
\text { digunakan dalam website }\end{array}$ & 4 & 4 \\
\hline 14. & Pemilihan font dalam website & 5 & 5 \\
\hline & $\begin{array}{l}\text { Kompatibilitas website dengan } \\
\text { berbagai macam browser }\end{array}$ & 5 & 5 \\
\hline 16. & $\begin{array}{l}\text { Kemudahan mendapatkan } \\
\text { plugin yang digunakan dalam } \\
\text { website }\end{array}$ & 4 & 4 \\
\hline 17. & $\begin{array}{l}\text { Tingkat kecepatan akses } \\
\text { website }\end{array}$ & 4 & 4 \\
\hline 18. & $\begin{array}{l}\text { Keefektifan penggunaan } \\
\text { media gambar/video }\end{array}$ & 5 & 5 \\
\hline 19. & $\begin{array}{l}\text { Tingkat ketersediaan koneksi } \\
\text { website }\end{array}$ & 5 & 5 \\
\hline \multirow[t]{3}{*}{20.} & $\begin{array}{l}\text { Kemudahan akses link untuk } \\
\text { website }\end{array}$ & 5 & 5 \\
\hline & Jumlah Skor & 90 & 91 \\
\hline & Rerata Skor & 4,5 & 4,55 \\
\hline
\end{tabular}


Tabel 6. Hasil Validasi Ahli Media 2

\begin{tabular}{|c|c|c|}
\hline No & Indikator & $\begin{array}{l}\text { Vali- } \\
\text { dasi } 1\end{array}$ \\
\hline 1. & Kemudahan website untuk dipelajari & 5 \\
\hline 2. & Penggunaan website mudah & 4 \\
\hline 3. & $\begin{array}{l}\text { Tingkat kesalahan penggunaan } \\
\text { hyperlink }\end{array}$ & 4 \\
\hline 4. & $\begin{array}{l}\text { Kejelasan navigasi yang digunakan } \\
\text { dalam website }\end{array}$ & 4 \\
\hline & Konsistensi navigasi & 5 \\
\hline 6. & $\begin{array}{l}\text { Visualisasi tombol yang digunakan } \\
\text { mudah di pahami }\end{array}$ & 4 \\
\hline 7. & Label navigasi mudah dimengerti & 5 \\
\hline 8. & $\begin{array}{l}\text { Kesesuaian komposisi warna yang } \\
\text { digunakan dengan target pengguna }\end{array}$ & 4 \\
\hline 9. & Konsistensi layout dalam website & 5 \\
\hline 10. & $\begin{array}{l}\text { Tata-letak (layout) bagian website } \\
\text { mudah dipetakan dengan jelas }\end{array}$ & 5 \\
\hline 11. & $\begin{array}{l}\text { Tingkat keterbacaan teks dalam } \\
\text { website }\end{array}$ & 5 \\
\hline & $\begin{array}{l}\text { Kualitas video yang ditampilkan di } \\
\text { dalam website }\end{array}$ & 4 \\
\hline & $\begin{array}{l}\text { Kualitas gambar yang digunakan } \\
\text { dalam website }\end{array}$ & 4 \\
\hline 14. & Pemilihan font dalam website & 5 \\
\hline 15. & $\begin{array}{l}\text { Kompatibilitas website dengan } \\
\text { berbagai macam browser }\end{array}$ & 5 \\
\hline & $\begin{array}{l}\text { Kemudahan mendapatkan plugin } \\
\text { yang digunakan dalam website }\end{array}$ & 5 \\
\hline 17. & Tingkat kecepatan akses website & 5 \\
\hline & $\begin{array}{l}\text { Keefektifan penggunaan media } \\
\text { gambar/video }\end{array}$ & 4 \\
\hline 19. & Tingkat ketersediaan koneksi website & 5 \\
\hline 20. & Kemudahan akses link untuk website & 5 \\
\hline Juml & lah Skor & 92 \\
\hline Rera & ta Skor & 4,6 \\
\hline
\end{tabular}

Sementara itu, ahli media 2 memberikan rerata skor 4,6 atau 'sangat baik' dalam menilai aspek media produk penelitian ini. Khusus untuk ahli media 2, proses validasi dilaksanakan hanya sekali karena produk telah dipandang layak untuk diujicobakan.

Setelah memberikan komentar, ahli media memberikan kesimpulan mengenai kelayakan produk yang dikembangkan dari aspek media. Adapun kesimpulannya adalah bahwa produk/program ini layak untuk ujicoba lapangan tanpa revisi, setelah sebelumnya direvisi untuk divalidasi kedua.
Revisi Produk dari Hasil Validasi Media

Satu saran yang diberikan oleh salah satu ahli media adalah meminta mencek kembali hyperlink yang digunakan, supaya tidak ada kesalahan. Dari saran yang diberikan tersebut, pengembang menindaklanjuti dengan mencek kembali link yang digunakan dan memperbaiki link yang tidak berjalan dengan semestinya.

Hasil Uji Coba

\section{Uji Coba Perorangan}

Tanggapan mahasiswa pada uji coba perorangan dijaring dengan menggunakan angket skala likert. Informasi yang ingin diperoleh adalah informasi mengenai kualitas website interaktif yang dikembangkan dilihat dari aspek pembelajaran, materi, tampilan dan pemrograman. Disediakan pula ruang untuk menuliskan komentar dan saran dari mahasiswa. Data tanggapan mahasiswa terhadap kualitas produk yang dikembangkan dapat dilihat pada tabel berikut.

Tabel 7. Penilaian Uji Perseorangan pada Dua Aspek dalam Pengembangan Website Interaktif

\begin{tabular}{lcc}
\hline Aspek Penilaian & $\begin{array}{c}\text { Rerata } \\
\text { Skor }\end{array}$ & Kategori \\
\hline Materi & 4,38 & Sangat baik \\
Media & 4,59 & Sangat baik \\
Rerata Skor & 4,48 & Sangat baik \\
\hline
\end{tabular}

Dari keenambelas indikator yang dijadikan acuan untuk memvalidasi website interaktif secara perorangan, tiga diantaranya mendapat skor 4 atau 'baik', sedangkan ketigabelas indikator yang lain dikategorikan 'sangat baik' dengan rerata skor bervariasi dari 4,33 hingga 5. Ketiga indikator tersebut meliputi keseusaian gambar dan video dengan materi serta tingkat kesalahan link (broken link) sedikit. Komentar subjek uji coba terhadap pengembangan website interaktif ini sebagai berikut: (a) website interaktif ini sangat membantu mahasiswa dalam menjembatani komuni- 
kasi antardosen dan mahasiswa serta antara mahasiswa; (b) website interaktif ini dilengkapi dengan input materi, kegiatan pembelajaran serta ilustrasi atau contoh yang sesuai dengan topik dan lebih menarik untuk dipelajari karena mengakomodasi audio dan visual; (c) desain website interaktif memungkinkan komunikasi terjadi dua arah dan menuntut partisipasi aktif dari mahaisiswa sehingga dapat menjadi ajang belajar mandiri dan kolaboratif, serta (d) ketepatan contoh-contoh untuk memperjelas isi atau materi sangat bagus, sehingga memperjelas semua materi dan tidak mendapat kesulitan.

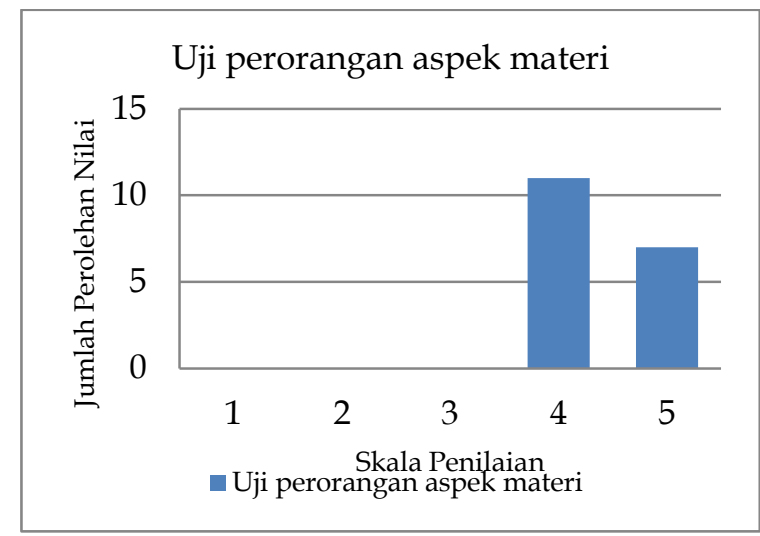

Gambar 1. Hasil Uji Perorangan Aspek Materi

\section{Revisi Produk Hasil Uji Coba Perorangan}

Satu-satunya masukan yang datang dari mahasiswa pada uji coba satu-satu (perorangan) ini adalah mengeluhkan mengenai kelambatan akses ke website jika diakses dari jaringan provider internet XL. Dari masukan tersebut, pengembang menindaklanjuti dengan menghubungi pihak web hosting Idwebhost, untuk meminta supaya dipindah letak hosting web server, yang semula diletakkan di server Amerika, untuk dipindah ke server Indonesia, supaya akses dalam negeri lebih cepat, karena mayoritas pengguna produk website interaktif ini berasal dari dalam negeri.

\section{Uji Coba Kelompok Kecil}

Data tanggapan mahasiswa dalam uji coba kelompok kecil terhadap website interaktif hasil pengembangan, dipaparkan dalam bentuk tabel tanggapan uji coba kelompok kecil yang memuat skor rerata masing-masing butir, dan skor rerata keseluruhan dari jumlah responden.

Pada validasi kelompok kecil, produk yang dikembangkan mendapat rerata skor 4,44 atau 'sangat baik'. Dari keenambelas indikator yang dinilai, hanya indikator komposisi warna yang digunakan yang dinilai 3,33 atau 'cukup'. Kejelasan materi, kesesuaian video, contoh dan gambar dinilai 'sangat baik' semua. Secara umum, website interaktif yang dikembangkan sangat mudah digunakan, dengan rerata skor 4,33 atau 'sangat baik'. Hal ini nampak dari penilaian terhadap website yang diberikan responden terhadap indikator kemudahan navigasi, label dan tombol yang mudah dipahami, yang kesemuanya dinilai 'sangat baik'.

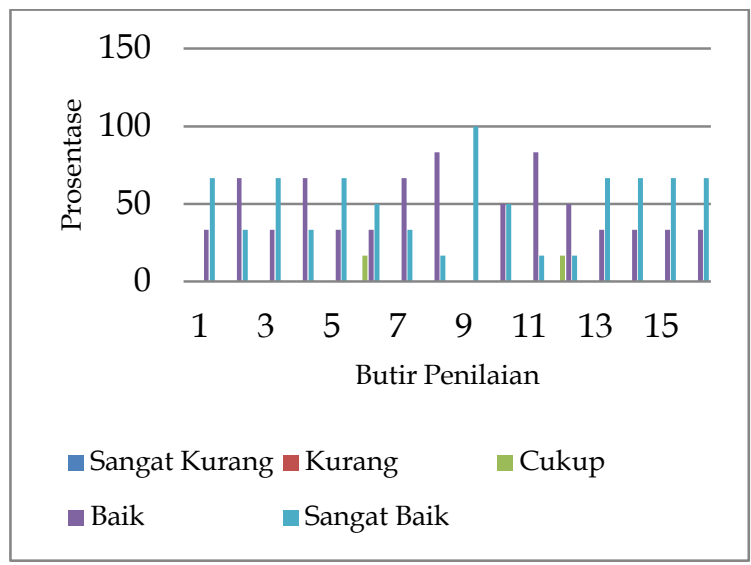

Gambar 2. Diagram frekuensi Diagram Freku-ensi Penilaian Aspek Materi dan Media pada Uji Coba Kelompok Kecil

Komentar dari responden pada uji coba kelompok kecil pada umumnya juga bersifat positif, yaitu: (a) website interaktif yang digunakan dinilai baik dan efektif digunakan dalam pembelajaran, memberi pengalaman langsung belajar menggunakan jaringan komputer atau website; (b) website interaktif ini sangat interaktif, sehingga memudahkan mahasiswa dalam berkomunikasi baik dengan sesama mahasiswa maupun dosen; (c) secara keseluruh- 
an, penjelasan serta ilustrasi yang disediakan mudah dimengerti dan sesuai; (d) website memiliki kejelasan gambar dan tulisan yang sesuai dengan latar; dan (e) website interaktif ini sangat bagus dan pantas untuk dikembangkan lebih lanjut.

Tabel 8. Penilaian Uji Perseorangan pada Dua Aspek dalam Pengembangan Website Interaktif

\begin{tabular}{lcc}
\hline $\begin{array}{c}\text { Aspek } \\
\text { Penilaian }\end{array}$ & Rerata Skor & Kategori \\
\hline Materi & 4,49 & Sangat baik \\
Media & 4,41 & Sangat baik \\
Rerata Skor & 4,44 & Sangat baik \\
\hline
\end{tabular}

Hasil Uji Coba Lapangan

Data tanggapan mahasiswa dalam uji coba lapangan terhadap website interaktif hasil pengembangan, dipaparkan dalam bentuk tabel tanggapan uji coba lapangan yang memuat skor rerata masingmasing butir, dan skor rerata keseluruhan dari jumlah responden, sebagai berikut.

Tabel 9. Penilaian Uji Perseorangan pada Dua Aspek dalam Pengembangan Website Interaktif

\begin{tabular}{lcc}
\hline Aspek Penilaian & Rerata Skor & Kategori \\
\hline Pembelajaran & 4,4 & Sangat baik \\
Isi/Materi & 4,53 & Sangat baik \\
Rerata skor & 4,48 & Sangat baik \\
\hline
\end{tabular}

Data hasil lapangan menunjukkan bahwa website interaktif yang dikembangkan, secara keseluruhan, dinilai 'sangat baik' dengan rerata skor 4,48. Untuk aspek materi, produk hasil pengembangan mendapat rerata skor 4,4 atau 'sangat baik', demikian juga untuk aspek media, 4,53 atau 'sangat baik'. Dari aspek materi, terdapat satu indikator saja yang dinilai 'baik' dengan rerata skor 4, 06, yakni indikator kecukupan contoh yang diberikan. Sedangkan untuk aspek media, keseluruhan indikator dianggap 'sangat baik' dengan rerata skor bervariasi dari rerata skor 4,33 hingga 4,73 .

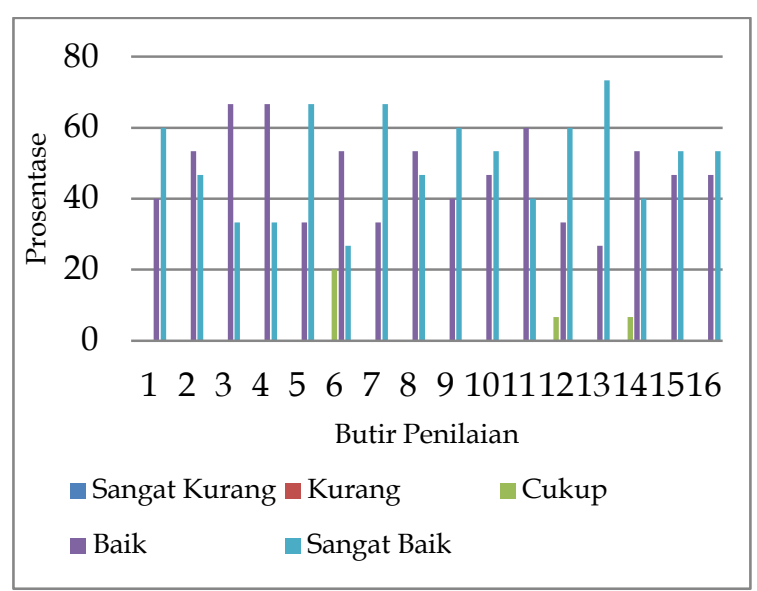

Gambar 3. Diagram Frekuensi Penilaian Aspek Materi dan Media pada Uji Coba Lapangan

Selain hasil validasi diatas, responden juga memberikan respon tertulis terkait kualitas video yang diakses melalui website hasil pengembangan, dimana video yang dilink-an pada youtube.com tersebut, saat diakses, tayangannya menjadi putusputus. Selebihnya, secara materi dan media, produk penelitian ini layak digunakan.

\section{Revisi Produk Hasil Uji Coba Lapangan}

Terdapat satu masukan dari mahasiswa mengenai akses video yang terputusputus ketika diakses olehnya. Pengembang mengatasi permasalahan tersebut dengan mengunggah video tersebut ke dalam youtube, tidak langsung di dalam server web. Dengan diunggahnya video ke dalam youtube dan di-embed ke dalam website interaktif, sesuai dengan fitur yang dimiliki youtube, pengguna mempunyai pilihan untuk dapat mengubah kualitas video sesuai dengan seberapa cepat koneksi internetnya. Juga dengan digunakannya youtube sebagai basis video, server web tidak lagi terbebani baik secara kapasitas penyimpanan atau juga kuota bandwidth.

Secara keseluruhan, wahana computer-mediated communication untuk pembelajaran Jaringan Komputer ini memiliki kelebihan sebagai berikut: (a) otentifikasi pengguna, yang diberikan melalui nama pengguna dan kata sandi; (b) dua tingkat akses, yaitu administrator dan pengguna 
biasa, dimana administrator memiliki seluruh akses yang ada pada website, termasuk pada membuat kategori, melakukan kustomisasi isi, dan beberapa fitur lainnya, sedangkan pengguna biasa hanya pada memanfaatkan dan berinteraksi saja; (c) pada halaman utama terdapat materi yang bisa diakses dan halaman interaksi yang dapat dimanfaatkan oleh para pengguna; (d) materi yang dimasukkan terdiri dari beberapa materi yang dikembangkan dari beberapa bagian silabus; (d) wahana untuk berkomunikasi, yang difasilitasi dengan bentuk komentar pada setiap materi, dan rating baik pada materi ataupun pada setiap komentar yang diberikan; serta (e) akses bagi pengguna untuk mengatur preferensi profil mereka, untuk menampakkan siapa pengguna tersebut, mulai dari nama asli, foto, e-mail, sampai pada menu penggantian password. Selain itu, dengan fitur-fitur yang interaktif, wahanan computer-mediated communication untuk pembelajaran Jaringan Komputer ini menyediakan materi konseptual maupun praktikal yang terkait dengan Jaringan Komputer secara akurat dan menarik dan fitur berdiskusi atau berinteraksi secara dua arah yang mendukung interaksi belajar antara mahasiswa maupun mahasiswa dan dosen secara dinamis.

\section{Simpulan dan Saran}

\section{Simpulan}

Berdasarkan hasil penelitian dan pengembangan wahana computer-mediated communication untuk pembelajaran Jaringan Komputer, maka disimpulkan bahwa: wahana CMC hasil pe-ngembangan ini layak digunakan dalam pembelajaran dibuktikan berdasarkan hasil validasi ahli materi dari aspek materi dan aspek pembelajaran mendapatkan rerata skor 4,48 dengan kategori "sangat baik". Sedangkan hasil validasi yang dilakukan oleh ahli media terhadap kualitas multi-media pembelajaran yang dikembangkan ditinjau dari aspek tampilan dan aspek pemrograman dengan rerata skor 4, kategori "sangat baik". dan hasil uji coba secara perorangan, kelompok kecil dan lapangan kepada mahasiswa yang mengambil kelas Jaringan Komputer di Jurusan Teknologi Pendidikan UNY, terhadap kelayakan wahana CMC untuk pembelajaran Jaringan Komputer yang dikembangkan dalam penelitian ini adalah "sangat baik". Hal ini berdasarkan perolehan skor rerata sebesar 4,16 atau 'baik' untuk aspek pembelajaran 4,33 atau 'sangat baik' dari segi materi, dari kedua ahli materi, dan skor rerata sebesar 4,55 atau 'sangat baik' dari kedua ahli media. Wahana CMC ini karenanya layak digunakan dan dapat mendukung efektivitas interaksi belajar antarmahasiswa maupun antara mahasiswa dan dosen yang dinamis.

Saran

Berdasarkan kesimpulan tersebut, maka untuk pemanfaatan lebih lanjut disarankan: (1) produk website interaktif ini dapat digunakan untuk mengakomodasi pembelajaran matakuliah selain jaringan komputer, yang membutuhkan interaksi sistem interaksi yang sama; dan (2) website interaktif ini perlu diimplementasikan pada kelompok mahasiswa jurusan Kurikulum dan Teknologi Pendidikan, Fakultas Ilmu Pendidikan, UNY, sebagai sasaran utama penelitian, pada saat berlangsungnya kegiatan perkuliahan, dengan terlebih dahulu membekali pengetahuan tentang dasar penggunaan dan etika berkomunikasi dalam dunia maya, baik dosen, maupun mahasiswa.implikatif dari temuan penelitian

\section{Daftar Pustaka}

Suyanto, A.H., (2007). Step by step web design theory and practices. Yogyakarta: Penerbit Andi.

Riza, B., (2012). Pengguna internet nomor 3 dunia . diakses tanggal 24 Desember 2012 dari http://www.tempo.co/read/news /2012/12/04/072445832/Indonesia 
-Pengguna-Internet-Nomor-3Dunia.

Douglas, K.M., \& McGarty, Craig. (2001). Identifiability and self-presentation: computer-mediated communication and in group interaction. The British journal of social psychology, 40 (Sept 2001), 399-416.

Dick, W., Carey, L., Carey, J.O. (2009). The systematic design of instruction. Merrill/Pearson.
Putra, L., \& Ishartiwi, I. (2015). Pengembangan multimedia pembelajaran interaktif mengenal angka dan huruf untuk anak usia dini. Jurnal Inovasi Teknologi Pendidikan, 2(2), 169-178. Retrieved from http://journal.uny.ac.id/index.php Ljitp/article/view/7607/6556

Sukardjo, (2010). Kumpulan materi evaluasi pembelajaran. Yogyakarta: Pascasarjana UNY. 